\title{
MODEL REVITALISASI RETROFITTING PADA KAWASAN WISATA KAMPUNG MADRAS MEDAN
}

\author{
Dwi Lindarto ${ }^{1}$, Devin Defriza Harisdani ${ }^{2}$ \\ 1,2 Departemen Arsitektur, Fakultas Teknik, Universitas Sumatera Utara, 20122 \\ dwi.lindarto@usu.ac.id
}

\begin{abstract}
ABSTRAK. Aglomerasi kawasan budidaya ditandai terkelompoknya kegiatan wisata kota, yang pada kenyataannya justru menurunkan daya tarik wisata kota itu sendiri. Kampung Madras di Kota Medan termasuk salah satu wilayah wisata kota lama yang mengalami penurunan vitalitas wisata berupa degradasi penampilan dan sedikitnya aktivitas wisata. Penelitian ini bertujuan menyusun model revitalisasi kawasan wisata berbasis retrofitting sub-urban. Metode Kualitatif Deskriptif dilakukan untuk mengungkap potensi genius loci sebagai unsur revitalisasi menjadikan Kampung Madras sebagai kawasan wisata Little Indian District kota Medan. Model revitalisasi Kampung Madras sebagai Cultural District City dapat diterapkan melalui 3 (tiga) cara antara lain: (1) melalui penataan fasada bangunan yang dibuat bercorak khas, dynamic skyline serta penataan pedestrian menjadi 3 jalur (window shopping lane, circulation lane, amenity lane) (2) Indian bridge and street carnival (3) Foodcourt Pagaruyung. Model revitalisasi ini memerlukan dukungan dan partisipasi para stake holder terutama masyarakat Tamil setempat berupa kegiatan culinary, occasion dan event khas meningkatkan vitalitas ekonomi dan pembentukan suasana Hindustan Kampung Madras.
\end{abstract}

Kata kunci: Kampung Madras, Revitalisasi, Retrofitting, Wisata Kota

ABSTRACT. Agglomeration cultivation area is centralized city tourism activities, which in fact worsened the city tourist attraction itself. Kampung Madras in Medan, one of the old town tourist area decreased vitality in an example, degradation of appearance and minimal tourist activity. This research aims to develop a revitalization model of the tourist area based on the sub-urban retrofitting concept. Qualitative Methods Descriptive conducted to revealed the genius loci potential as an element of revitalization to make Kampung Madras be a tourist area Little Indian District of Medan. Revitalization model of Kampung Madras as the Cultural District City can be applied through three ways, among others: (1) through the arrangement of buildings facade typical patterned, dynamic skyline and pedestrian (window shopping lane, circulation lane, amenities lane) (2) Indian bridge and street carnival (3)Pagaruyung foodcourt. These revitalization models require the support and participation of stakeholders, especially the local Tamil community in the act of culinary activity, occasion and event that increase economic vitality and the establishment of Kampung Madras Hindustan atmosphere.

Keywords: Kampung Madras, Revitalization, Retrofitting, City Tourism

\section{PENDAHULUAN}

Perkembangan pembangunan wilayah pusat kota menunjukkan aglomerasi kegiatan wisata kota yang terencana secara formal maupun informal. Dalam kenyataannya tidak semua kawasan wisata kota mampu menampilkan perwajahan urban economics yang menarik bahkan mengindikasikan penurunan vitalitas kawasan wisata kota[1].

Salah satu kawasan wisata kota lama terkenal di Kota Medan adalah Kawasan Wisata Kampung Madras yang dahulunya dikenal sebagai Kampung Keling di Jalan Zainul Arifin Medan. Sejarah menyatakan kawasan ini merupakan kawasan wisata dengan ikon kuil Shri Marriaman yang legendaris sebagai Kuil Hindu Asia seperti yang ada di Kota Singapore dan Penang. Kondisi infrastruktur kawasan menunjukkan stagnasi akomodasi kegiatan wisata. Kawasan Kampung Madras sebagai kawasan kota tua Medan memiliki potensi daya tarik lokal antara lain arsitektur kuil Hindu dan kegiatan perdagangan khas India Tamil. Ruas jalan Zainul Arifin dengan nodal Sun Plaza dan Hotel SwissBell tidak mampu menarik wisatawan berwisata city-walk terutama karena tatanan land use kawasan, pemanfaatan lahan dan street furniture yang tak memadai sehingga berakibat degradasi vitalitas kawasan ini. Memudarnya citra Kampung Madras sampai pada titik memprihatinkan hingga sangat diperlukan tindak revitalisasi kawasan untuk menunjang pengembangan wilayah kota Medan. 


\section{Model Urban Tourism}

Konsep pengembangan kawasan urban tourism kekinian menyuguhkan 6 model yaitu tourist-historic city, cultural city, resort city, fantasy city, creative city, dan urban ecotourism. Tourist-historic city berkembang sejak abad ke-16 seiring dengan perkembangan pariwisata perkotaan[2]. Konsep ini menjadikan sejarah sebagai daya tarik wisatanya dengan komponen antara lain lingkungan dengan arsitektur sejarah dan morfologi perkotaan, even sejarah dan akumulasi artefak budaya, keberhasilan artistic [3].

Cultural city diidentikkan dengan kota sejarah atau kota heritage. Daya tarik wisata utama bagi kota-kota budaya adalah: 1) museum dan wisata heritage, 2) distrik-distrik budaya (pecinan, kampong arab), 3) masyarakat etnis, 4) kawasan hiburan, 5) wisata ziarah, 6) trail sastra[4].

Fantasy city, Konsep kota fantasi muncul pada akhir abad ke-19 di Amerika dengan karakter pada themocentricity, The city is aggressively branded, Day and night operation is a common feature, Modularisation of products, Solipsisicity, 'kota ilusi', Postmodernity simulasi, realitas virtual, dan hiperrealitas[5].

Creative city (new urban tourism), Kota kreatif ditetapkan berdasarkan spectrum industri kreatif[6].

Model revitalisasi kawasan wisata kota salah satunya adalah retrofitting, yaitu suatu pendekatan revitalisasi yang berbasis kearifan lokal[7]. Model ini berupa pengungkapan potensi local wisdom (sejarah, makna, keunikan lokasi dan citra tempat) dengan penekanan terhadap penggalian potensi kearifan lokal yang disebut genius loci atau esensi/jiwa tempat[8]. Dengan pendekatan retrofitting diharapkan dapat dirumuskan suatu konsep revitalisasi Kampung Madras menjadi kawasan growth centre berbasis wisata.

\section{METODE PENELITIAN}

Rancangan penelitian pada tahap awal adalah identifikasi kearifan lokal (genius loci dan place attachment) kawasan dengan model Kualitatif Deskriptif mengumpulkan data berupa jenis kegiatan, pemanfaatan ruang wisata, model tatanan wisata kota, sarana dan prasarana wisata dan arsitektur di identifikasi dengan cara observasi langsung di lapangan dalam bentuk rekaman foto dan narasi kegiatan. Observasi dilakukan pada saat kegiatan berlangsung siang hari (jam 10.00 15.00) dan malam hari (jam 19.00 - 21.00).

Dengan tujuan mengungkap tempat yang menarik bagi masyarakat untuk berkegiatan wisata maka digunakan metode mixed-method dengan strategi place eksplorasi[9], melakukan observasi langsung terhadap variabel tempat yang mencirikan landmark, edge, nodes, path dan district[10] di lapangan. Tempat dengan ciri demikian dimaknai memiliki kekuatan daya tarik citra kota (sense of place) yang kuat. Atas tempat berkarakter tersebut dilakukan jajak pendapat terhadap masyarakat wisata sejumlah 50 responden wisatawan dan masyarakat yang berkegiatan wisata di Kampung Madras. Analisis kemudian dilakukan dengan metode skoring skala likert untuk memperoleh tingkat daya tarik tempat berkarakter sesuai dengan keramaian pengguna tempat tersebut.

Konsep penataan revitalisasi kawasan wisata kota Kampung Madras akan disempurnakan dalam bentuk model perancangan desain revitalisasi kawasan dengan pendekatan retrofitting urban[11] yang mengolah linkage visual terhadap unsur tata guna lahan, arsitektur lokal, sirkulasi, ruang terbuka publik, aktifitas khas lokal, dan signage[12].

Metode pengumpulan data yang dilakukan dibagi berdasarkan sistem analisis data yang digunakan. Untuk Analisis Figure/Ground akan digunakan teknik pengumpulan data berupa observasi terhadap pola fungsional kawasan dengan gambaran struktur pokok bangunan yang ada (eksisting). Untuk analisis citra kota (sense of place), teknik pengumpulan data yang digunakan adalah observasi terhadap elemen citra kota yaitu: path (jalur), edge (tepian), district (kawasan), node (simpul), landmark (tengeran) serta wawancara untuk menentukan tingkat ketertarikan terhadap elemen citra kota yang ada. Analisis place dan linkage visual akan menggunakan teknik superimposse spatial[13].

\section{HASIL DAN PEMBAHASAN}

\section{Analisis Figure/Ground Fungsional}

Analisis figure/ground yang digunakan adalah sejalan dengan analisis yang dilakukan oleh Giambatista Nolli[14], yaitu tidak hanya menggambarkan pola kawasan secara solid/void saja namun menambahkan pola fungsional kawasan dengan gambaran struktur pokok bangunan yang ada (eksisting). 


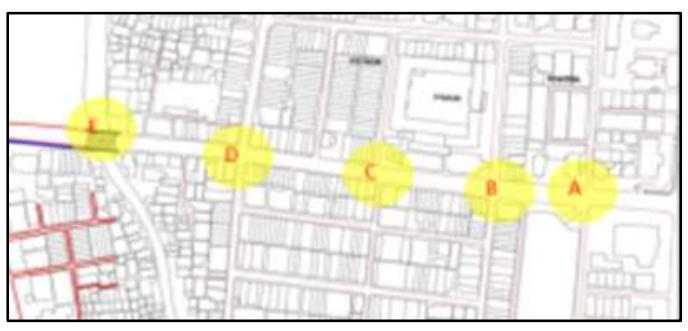

Gambar 1. Analisis Figure/Ground Fungsional (Sumber: analisis peneliti, 2018)

Dari hasil analisis maka didapati terdapat urban fabric void yang potensial untuk dimanfaatkan sebagai suatu ruang terbuka publik:

Void A (perempatan Jalan Diponegoro)

Void B (simpang Jalan Cut Nya Dien)

Void C (perempatan Jalan Pagaruyung)

Void D (kawasan jalan Teuku Umar)

Void E (kawasan jembatan kebajikan)

\section{Analisis Citra Kota}

Sense of place atau citra kota merupakan imaji menarik sesuai persepsi atau gambaran mental masyarakat oleh daya tarik kawasan. Elemen citra kota yaitu path (jalur), edge (tepian), district (kawasan), node (simpul), landmark.

Path (jalur) merupakan jalur sirkulasi yang dilalui orang berpindah. Path akan mempunyai identitas yang baik jika punya tujuan yang jelas dan diperkaya oleh elemen penanda arah yang kuat (deretan fasad bangunan, jajaran pohon, penunjuk arah dsb).

Edge (tepian) merupakan pembatas antar dua kawasan dan berfungsi sebagai pemutus jalur linear. Edge bersifat referensif. Edge merupakan pengakhiran suatu district yang beridentitas jika kontinuitas yang dibentuknya bersifat memperjelas sebagai pemutus atau penyambung antar kawasan.

District (kawasan) menjadi identitas jika mempunyai ciri khas yang mirip (bentuk, pola dan wujudnya) tampilan homogen elemen bangunan yang berada pada suatu kawasan baik fungsi maupun posisinya.

Node (simpul) merupakan pertemuan aktifitas antar jalur. Node adalah tempat dimana orang merasa masuk dan keluar (perubahan arah dan ruang).

Landmark (tengeran) merupakan bentuk eksternal yang lebih menonjol dalam bentuk visualnya. Landmark membantu orientasi seseorang terhadap daya tarik tempat.

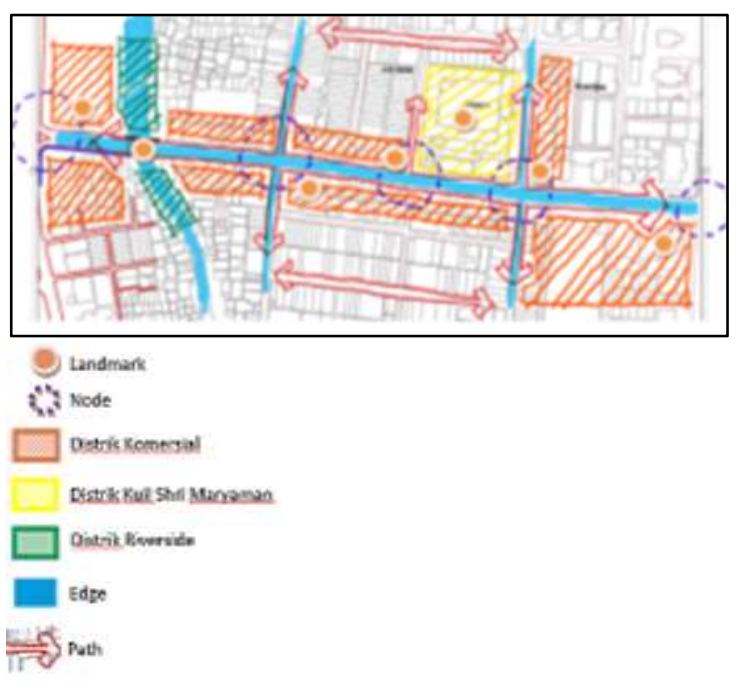

Gambar 2. Identifikasi citra kota Kampung Madras (Sumber: analisis peneliti, 2018)
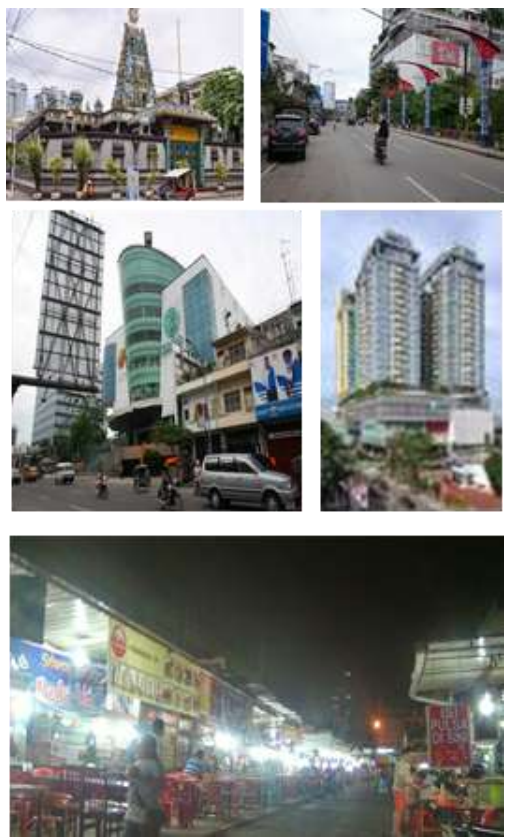

Gambar 3. Gambaran potensi citra kota Kampung Madras

(Sumber: observasi peneliti, 2018)

Dari hasil kuesioner mengenai ketertarikan masyarakat wisata terhadap ruang wisata di kawasan kampung Madras maka dengan tabulasi berskala likert menunjukkan frekuensi ketertarikan masyarakat kepada obyek wisata di Kampung Madras sebagai berikut: 


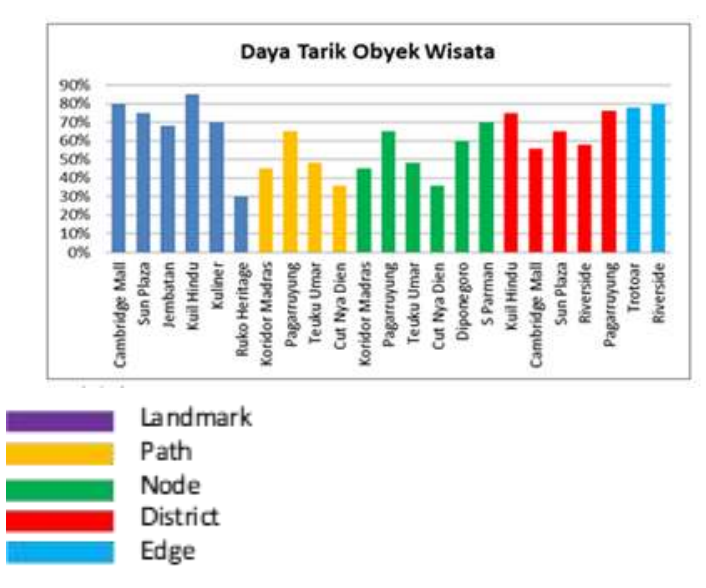

Gambar 4. Analisis daya tarik objek (Sumber: analisis peneliti, 2018)

Terdapat beberapa tempat yang dianggap cukup menarik yaitu : Kuil Shri Maryamman merupakan landmark menonjol ( $\mathrm{f}=85 \%$ ), jalan Pagaruyung merupakan path yang menarik $(f=65 \%)$, jalan $S$. Parman merupakan node yang menarik diminati $(f=70 \%)$, Kuil Hindu dan Pagaruyung merupakan distrik yang menarik $(\mathrm{f}=75 \%$ rata-rata), trotoar dan riverside sebagai tepian/edge yang paling menarik ( $f=85 \%$ ratarata).

\section{Analisis Place}

Hakikat tempat yang berfungsi terletak pada pemahaman budaya dan karakteristik manusia terhadap tempatnya. Suatu tempat atau place adalah space (ruang) yang memiliki suatu ciri khas tersendiri. Sebuah space akan menjadi place kalau mempunyai arti dari lingkungan yang berasal dari kebiasaan budaya daerahnya[15].

Pemahaman place (tempat) diperdalam dengan konsep space-time conception dengan menempatkan kegiatan / perilaku manusia dengan mengkonkretkan occasion (kejadian/peristiwa). Teori tentang tempat (place) dipergunakan untuk mengungkap potensi lokasi atau tempat yang ada di kawasan Kampung Madras dengan melihat korelasi adanya tempat untuk beraktifitas secara rutin dan berdaya guna.

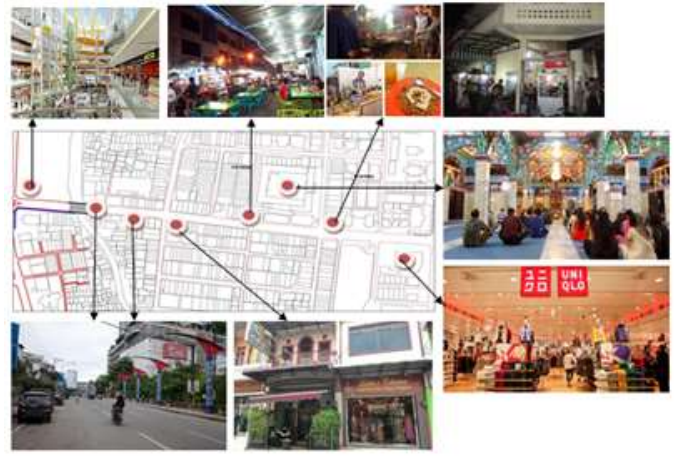

Gambar 5. Analisis Place

(Sumber: analisis peneliti, 2018)

\section{Analisis Linkage Visual}

Salah satu metode perancangan kota adalah model Linkage visual[16] yang membahas mengenai hubungan suatu tempat dengan tempat lainnya sebagai generator revitalisasi suatu kawasan. Teori ini menegaskan hubungan dan sirkulasi gerakan dinamis suatu kegiatan di perkotaan sebagai suatu urban fabric.

Dalam penelitian rencana revitalisasi kawasan Kampung Madras ini dilakukan analisis kemungkinan potensi penguatan linkage visual antar pusat kegiatan yang dapat terdeteksi melalui tingkat keramaian dan kemungkinan penguatan potensi linkage visual di area tersebut. Analisis tersebut dapat dilihat pada gambar superimpose pusat kegiatan dan sirkulasi penghubung visual berikut:

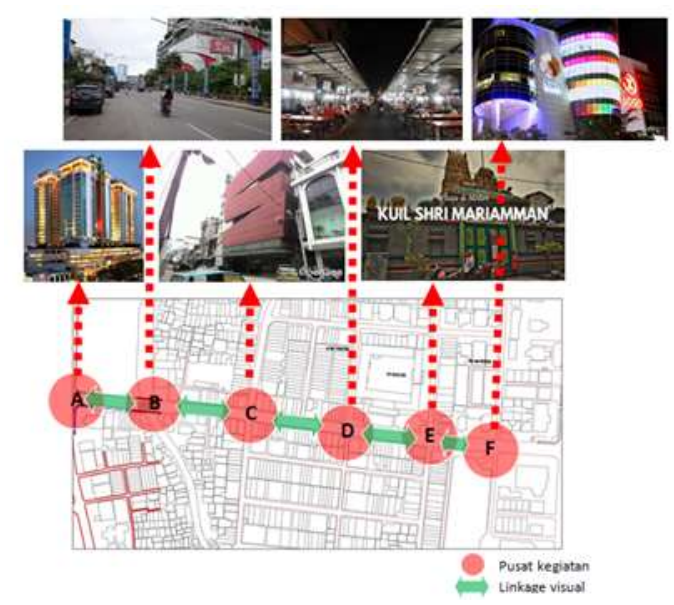

Gambar 6. Analisis Linkage Visual (Sumber: analisis peneliti, 2018)

Terhadap analisis potensi kearifan lokal (genius loci) kawasan Kampung Madras yang telah dilakukan dengan metode analisis gabungan yaitu analisis Figure / Ground fungsional[17], analisis citra kota (Sense of 
Place)[18], Analisis Place[19], dan analisis Linkage Visual[20], dilakukan pembahasan untuk mengungkapkan lokasi potensial kawasan Kampung Madras sebagai prioritas dalam penyusunan konsep revitalisasi kawasan.

Tabel 1. Rangkuman Analisis Potensi Lokasi Revitalisasi Kampung Madras

\begin{tabular}{|c|c|c|c|c|c|c|}
\hline $\begin{array}{c}\text { Lokasi } \\
\text { OasarAnalisis }\end{array}$ & $\begin{array}{c}\text { Lokasi } \\
\text { A }\end{array}$ & Lokasi B & Lokasi & Lokasi D & LokasiE & Lokasif \\
\hline Figure:Ground & Goundvoid & Goundrod & Goundvid & Gounduod & GroundVod & GroundVoid \\
\hline Sense Of place & $\begin{array}{l}\text { Landmakk, } \\
\text { Node. Distict }\end{array}$ & $\begin{array}{l}\text { Landmaks } \\
\text { Node.Path }\end{array}$ & Node, Path & Node, Path & $\begin{array}{l}\text { Landmak, } \\
\text { Node.Päh }\end{array}$ & $\begin{array}{l}\text { Landmak, } \\
\text { Node, Distict }\end{array}$ \\
\hline Place Concept & $\begin{array}{l}\text { Entrance } \\
\text { Gateway }\end{array}$ & $\begin{array}{l}\text { Plaza } \\
\text { Square }\end{array}$ & $\begin{array}{l}\text { Streetmaket } \\
\text { dannight } \\
\text { maket }\end{array}$ & $\begin{array}{l}\text { Streat maket } \\
\text { dannight } \\
\text { maket }\end{array}$ & $\begin{array}{l}\text { Plaza } \\
\text { Squase }\end{array}$ & $\begin{array}{l}\text { Entrance } \\
\text { Gatenay }\end{array}$ \\
\hline Liakage Visual & $\begin{array}{l}\text { Potensial } \\
\text { Gakage ABBas } \\
\text { serialvision }\end{array}$ & $\begin{array}{l}\text { Potensal } \\
\text { Enkage BC } \\
\text { asseral vision }\end{array}$ & $\begin{array}{l}\text { Potetsial } \\
\text { Inlage CD } \\
\text { asserialvision }\end{array}$ & $\begin{array}{l}\text { Potensal } \\
\text { Entage DE } \\
\text { as serialvision }\end{array}$ & $\begin{array}{l}\text { Potensial } \\
\text { inlogetef } \\
\text { asserial } \\
\text { vison }\end{array}$ & $\begin{array}{l}\text { Potensial } \\
\text { inkagefFE } \\
\text { asseral } \\
\text { vision }\end{array}$ \\
\hline
\end{tabular}

Sumber: analisis peneliti, 2018

Lokasi-lokasi tersebut menjadi prioritas untuk pengembangan model Revitalisasi kawasan Kampung Madras dengan mempertimbangkan potensi Genius Loci yaitu:

a. Sense of Place : Tampil sebagai landmark dan node

b. Visual Linkage : Menciptakan sequences serial vision kegiatan wisata di sepanjang koridor Kampung Madras Jalan Zainul Arifin

c. Variasi kegiatan berkarakter:

i. Street market - Night Market : Hawkers, dan Culinair tourism

ii. City Walk - Art and Culture attraction, Shopping, Hang Out, Selfie dan outdoor leisure tourism

iii. Hindu Rituals Attraction pada kuil Shri Marryamann

Dengan memperhatikan hasil analisis yang menghasilkan potensi kegiatan dan lokasi/tempat yang dapat dipergunakan sebagai prioritas bagi kegiatan penyusunan model perencanaan revitalisasi kampung Madras maka berikut disampaikan konsep penataan kawasan koridor Kampung Madras sebagai berikut :

\section{Penataan facada bangunan dan pedestrian}

Idea konsep dasar penataan fasada ruko berupa pewarnaan dimana bangunan di kawasan ini dibuat berwarna warni untuk menciptakan suasana ceria dan unik, sama seperti desain fasad bangunan di Little India Singapore yang menerapkan fasad bangunan berwarna-warni untuk mengurangi kemonoton-an dan lebih indah secara visual.

Ketinggian bangunan, dimana pada desain, semua bangunan memiliki tinggi yang sama rata yaitu 3 lantai dimana lantai pertama merupakan tempat untuk berdagang atau komersial. Ketinggian bangunan yang sama juga menciptakan skyline yang bagus dan simetris.

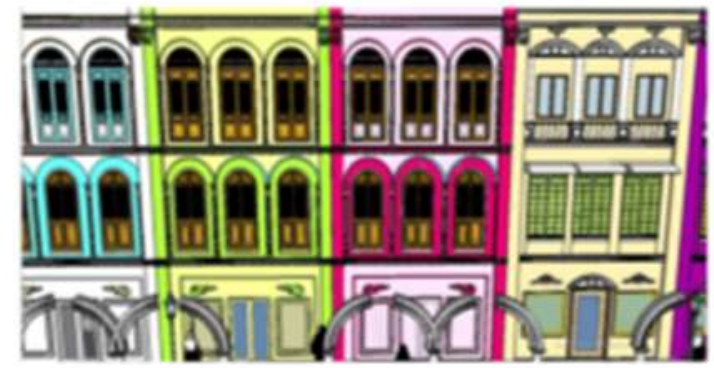

Gambar 7. Ide Penataan Fasade Bangunan

Pedestrian di jalan K.H.Zainul Arifin juga berpotensi untuk didesain dengan pola gapura Hindu India Tamil.

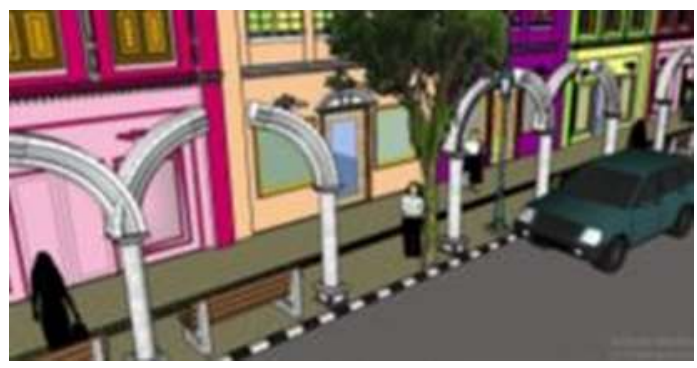

Gambar 8. Ide Penataan Pedestrian

Secara desain dapat diterapkan pola pedestrian yang sehat dan baik dimana jalur pedestrian dibagi menjadi 3 bagian yaitu : (1) Window shoping lane; (2) Circulation lane; (3) Amenity lane.

\section{Penataan jembatan dan area tepi sungai}

Railing Jembatan berpotensi untuk dilekatkan patung Dewa agama Hindu untuk mempererat kesan "India" di daerah Kampung Madras. Pada jembatan ini juga di desain jalur untuk berjalan kaki untuk menikmati pemandangan ke sungai maupun kebawah sungai. Pada samping jembatan, disediakan tangga yang cukup lebar sebagai jalur menuju ke area tepi sungai , atau bisa juga sebagai tempat duduk untuk menikmati suasana di tepi sungai. 


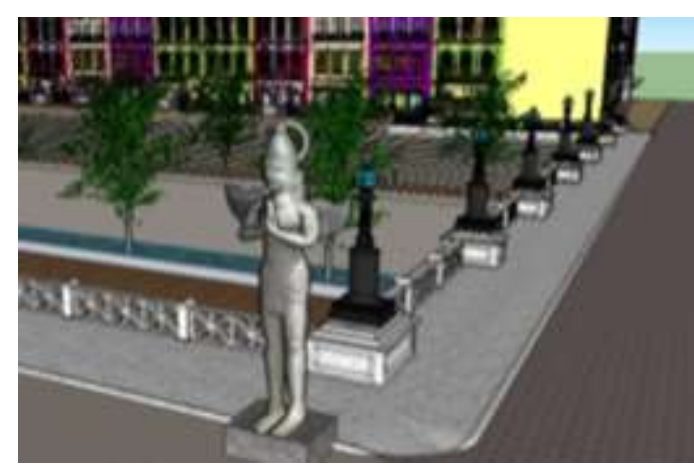

Gambar 9. Ide Penataan Jembatan

Daerah tepi sungai yang dahulu merupakan kawasan hunian kumuh berpotensi menjadi tempat kuliner layaknya food court. Kegiatan ini akan aktif pada siang dan malam hari sebagai Night Market didaerah Kampung Madras sebagai penambah aktifitas dan peramai kawasan tersebut. Akan terdapat stall makanan dan minuman untuk memenuhi kebutuhan kuliner wisatawan. Suasana di area tepi sungai ini akan sejuk dan menarik dikunjungi. Adanya jalur di antara deretan dagangan membuat sirkulasi pejalan kaki lebih lancar dan tidak mengganggu orang yang ingin duduk untuk makan minum. Vegetasi dimanfaatkan sebagai perindang dan filter cahaya matahari dan debu.

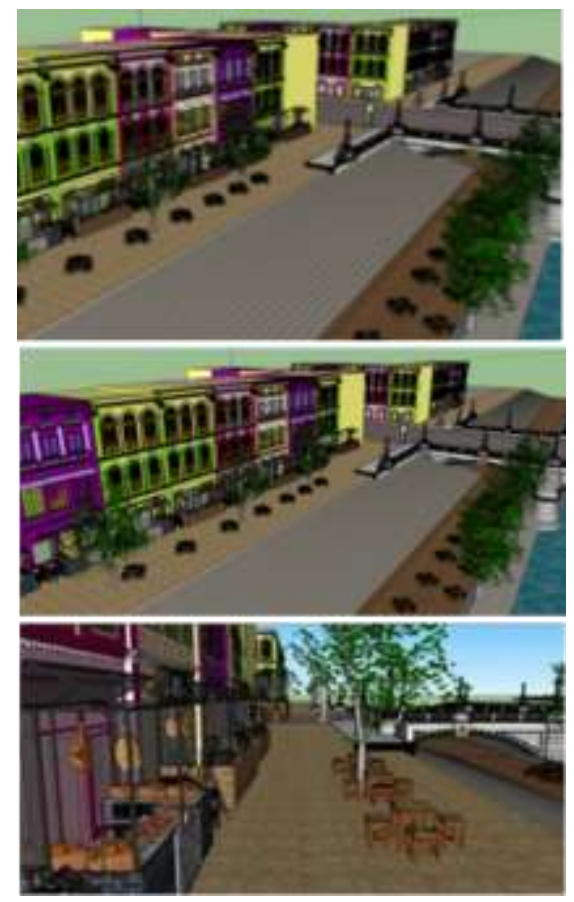

Gambar 10. Ide Penataan Tepi Sungai

3. Penataan tempat kuliner Pagaruyung

Pagaruyung foodcourt merupakan jalan yang dipenuhi oleh stall-stall makanan namun tempat ini membutuhkan perawatan dan perbaikan agar menjadi lebih baik dan lebih rapi. Sirkulasi kendaraan bermotor ditutup sehingga jalan ini hanya boleh dilalui oleh pejalan kaki, Kawasan ini di desain layaknya night market dimana sisi samping dan kiri jalur pejalan kaki dibatasi dengan stall-stall makanan, kemudian terdapat tempat duduk dan pepohonan di tengah jalan. Kursi dan meja makan terletak di sudut jalan di samping stall-stall makanan.
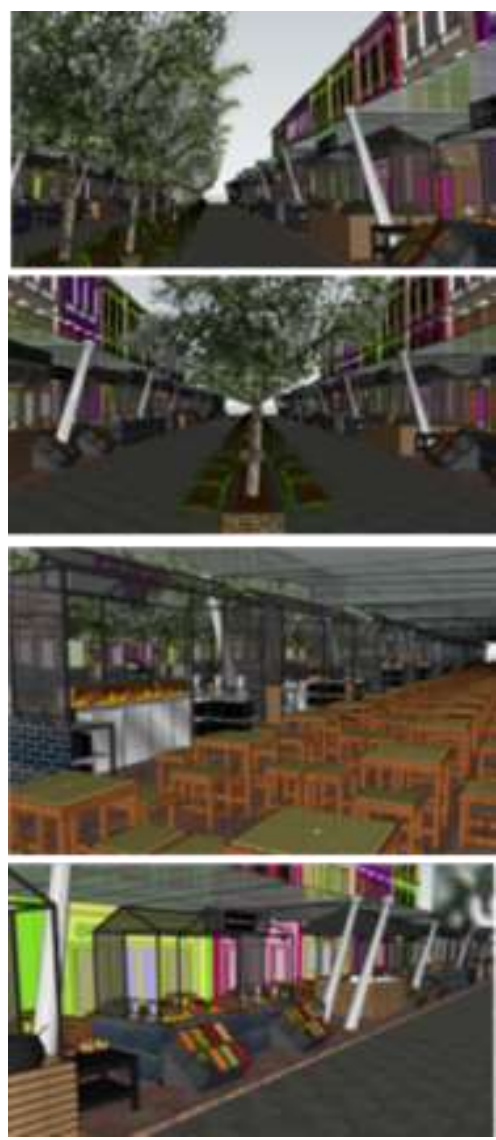

Gambar 11. Ide Penataan Kuliner Paguruyung

4. Model Revitalisasi Wisata Kampung Madras

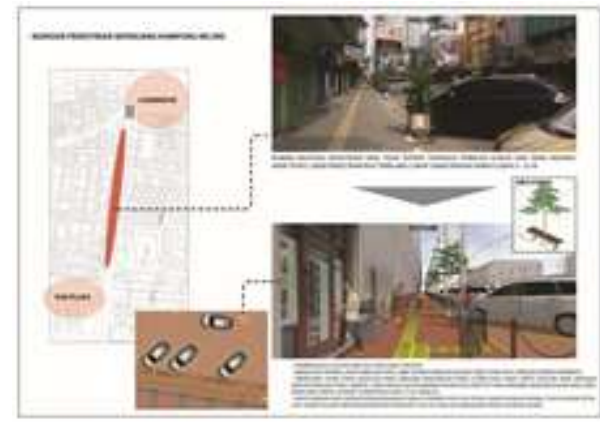

Gambar 12. Model Penataan Pedestrian 


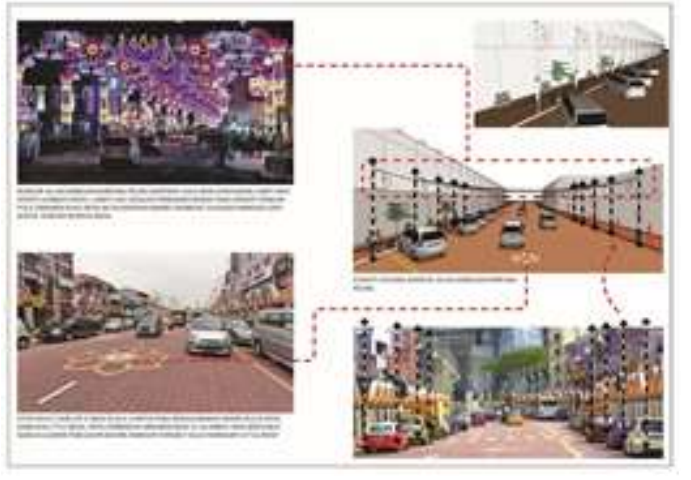

Gambar 13. Model Penataan Koridor Jalan

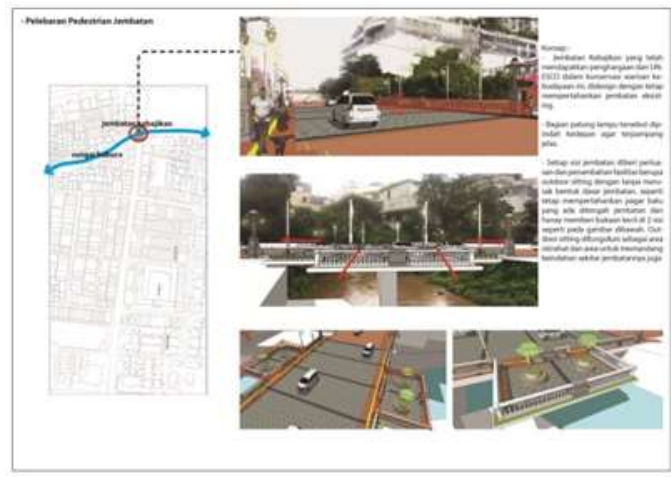

Gambar 14. Model Penataan Pedestrian Jembatan

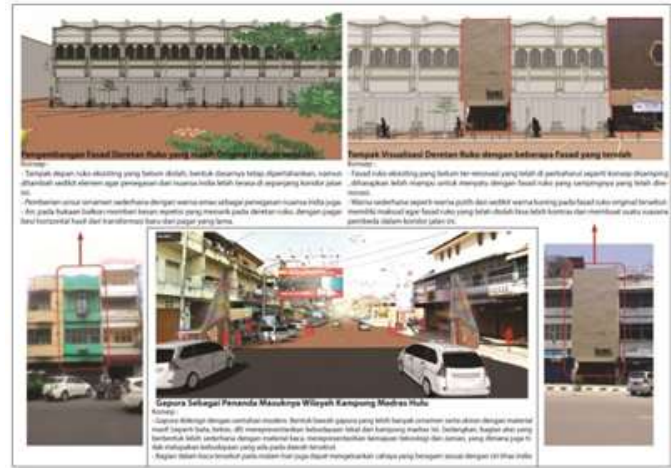

Gambar 15. Model Penataan Fasad Bangunan dan Gapura

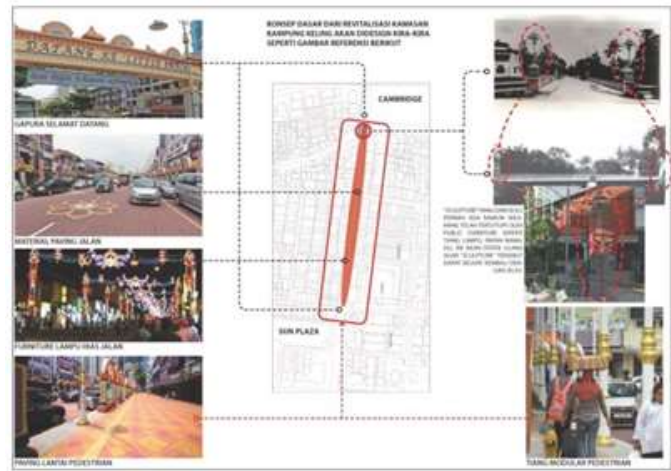

Gambar 16. Model Revitalisasi Kawasan

\section{KESIMPULAN}

Sesuai dengan potensi karakter budaya setempat maka Kampung Madras Medan berpotensi sebagai unsur penguat Cultural City dengan pengembangan kawasan wisata melalui pendekatan retrofitting (yakni upaya menggali kearifan lokal suatu kawasan), Model revitalisasi Kampung Madras dapat diterapkan melalui 3 (tiga) cara antara lain : (1) melalui penataan fasada bangunan yang dibuat bercorak khas India Tamil, dynamic skyline serta penataan pedestrian menjadi 3 jalur (window shopping lane, circulation lane, amenity lane); (2) Indian bridge and street carnival; (3) Foodcourt Pagaruyung. Model revitalisasi ini memerlukan dukungan dan partisipasi para stake holder setempat terutama masyarakat Tamil berupa kegiatan culinary, occasion dan event khas meningkatkan vitalitas ekonomi dan suasana Hindustan Kampung Madras.

\section{UCAPAN TERIMA KASIH}

Terima kasih kepada Lembaga Penelitian Universitas Sumatera Utara atas pendanaan penelitian ini dengan judul Model Revitalisasi Kawasan Wisata Kampong Keling Medan Berbasis Retrofitting Architecture, Penelitian Terapan, sesuai dengan Kontrak Pelaksanaan Penelitian TALENTA Universitas Sumatera Utara Tahun Anggaran 2018-Nomor 2590/UN5.1.R/PPM/2018 Tanggal 16 Maret 2018.

\section{DAFTAR PUSTAKA}

[1] Lynch, K. (1960). The Image of The city. The M.I.T. Press. Cambridge, Massachusetts.

[2] Asworth G.J. dan Tunbridge, J.E. (1990). The Tourist-Historic City , John Wiley\&Sons, England. p-57.

[3] Asworth G.J. dan Tunbridge, J.E. (1990). The Tourist-Historic City , John Wiley\&Sons, England. p-72.

[4] Richard G, Wilsin J (2008). Tourism, Creativity and Development, Routledge, Oxon.

[5] Page, SJ, Hall MC (2003). Managing Urban Tourism, Pearson Education Limited, Harlow.

[6] Richard G, Wilsin J (2008). Tourism, Creativity and Development, Routledge, Oxon.

[7] Dunham-Jones, E., \& Williamson, J. (2009). Retrofitting Suburbia: Urban Design Solutions for Redesigning 
Suburbs. Hoboken, NJ: John Wiley \& Sons.

[8] Norberg-Schultz, C. (1979). Genius Loci, Rizolli International Publications, New York.

[9] Creswell, J.W. (2014). Research Design: Qualitative, Quantitative, and Mixed Methods Approaches. California: Sage Publications, Inc.

[10] Lynch, K. (1960). The Image of The city. The M.I.T. Press. Cambridge, Massachusetts.

[11] Dunham-Jones, E., \& Williamson, J. (2009). Retrofitting Suburbia: Urban Design Solutions for Redesigning Suburbs. Hoboken, NJ: John Wiley \& Sons.

[12] Shirvani, H. (19850. The Urban Design Process., Van Nostrand Reinhold, New York

[13] Creswell, J.W. (2014). Research Design: Qualitative, Quantitative, and Mixed Methods Approaches. California: Sage Publications, Inc.

[14] Zahnd, Markus. (2006). Perancangan Kota Secara Terpadu. Kanisius, Yogyakarta.

[15] Norberg-Schultz, C. (1979). Genius Loci, Rizolli International Publications, New York.

[16] Bacon, E N. (1978). Design of Cities. Penguin books, New York.

[17] Zahnd, Markus. (2006). Perancangan Kota Secara Terpadu. Kanisius, Yogyakarta.

[18] Lynch, K. (1960). The Image of The city. The M.I.T. Press. Cambridge, Massachusetts.

[19] Norberg-Schultz, C. (1979). Genius Loci, Rizolli International Publications, New York.

[20] Bacon, E N. (1978). Design of Cities. Penguin books, New York. 